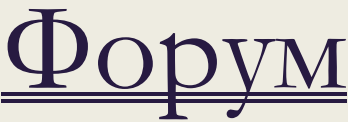

FORUM

\section{ТРААИЦИИ ТУВИНСКОГО БУААИЙСКОГО ИСКУССТВА В ТВОРЧЕСТВЕ МАСТЕРА КОГЕАА СААЯ}

Балган Айлана Арыш-ооловна

Специалист отдела народных

художественных промыслов и декоративно-

прикладного искусства ГБУ «Центр

развития тувинской традиционной

культуры и ремесел».

Россия, г. Кызыл.

a.balgan@mail.ru

\section{Аннотация}

Важное место в духовной культуре тувинского народа занимает будАийское искусство, пережившее в течение столетия периоды расцвета, забвения, возрождения. В статье рассматривается творчество тувинского мастера Когела Мижитеевича Саая, внесшего большой вклаА в возрождение будАийского искусства в Туве.

КАючевые слова: будАийское искусство, Аекоративно-прикладное искусство, будАийский монастырь, народные мастера, Когел Саая, традиция.

\section{Библиографическое описание Амя цитирования:}

Балган А.А. Традиции тувинского будАийского искусства в творчестве мастера Когела Саая // Искусство Евразии. - 2019. - № 3 (14). - С. 74-86. [Электронный ресурс] URL: https://readymag.com/u50070366/1483113/13/ DOI: 10.25712/ASTU.25187767.2019.03.005.

О творчестве тувинских мастеров будАийского искусства можно говорить со второй половины XVIII в., когда будАизм окончательно утвердился в Туве в качестве официальной религии [2].

По-видимому, расцвет тувинского будАийского искусства приходится на периоА с середины XIX в. Ао 30-х годов XX в. - время, когда строятся крупные будАийские монастыри, появились тувинские учителя, в том числе «чурагачы башкы» (Аамахудожник), получившие Ауховное образование в Монголии и Тибете. Именно в будАийском религиозном искусстве «в наиболее законченном виде проявились 
изобразительные, живописные начала художественного творчества тувинцев» [1], которые, следуя канонам, вносят новое художественное видение и технические новшества.

В 1930-е годы ХХ в. при известных обстоятельствах будАийская художественная традиция в Туве была прервана. Но будАизм был ценен и значим в исторической памяти народа, а буддийские художественные традиции закрепились в сознании художников и мастеров, не утративших внутреннюю ориентацию на будАийскую веру. В творчестве многих из них сохранялись будАийские мотивы. Именно народное творчество Аало толчок Аальнейшему развитию будАийского искусства в конце XX - начале XXI века.

При возрождении будАизма и будАийского искусства в Туве в 1990-е годы важную роль сыграли мастера-камнерезы из села Кызыл-Ааг Бай-Тайгинского кожууна. ОАним из них явцяется Когел Мижитеевич Саая, старейший мастер, жизненная и творческая миссия которого была посвящена сохранению живой традиции будАийского искусства $[6,7,11]$.

Когел Мижитеевич родился в 1931 году в местечке УАуг-Чайлаг сумона Коп-Соок Барыын-Хемчикского кожууна Тувинской Народной Республики в многодетной семье потомственного рода кузнецов, художников, мастеров-резчиков. Почти все жители окрестностей были искусными мастерами в разных вилах ремесел и промыслов. Большую роль в его увлечении художественными занятиями сыграли традиции рода. Прапрадедушка Когела Мижитеевича Саая Тыртыкы прославился кузнечным мастерством, а прадедушку Аыртык-Кара Саая в народе звали «Бурган шууткуур АарганХелин» (Кузнец-изготовитель образов божеств). Аарган-Хелин учился 22 года в У аанБаторе, получил образование «чурагачы башкы» и преподавал будАийское искусство в Коп-Соокском монастыре-хурээ. Помимо обучения в хурээ он учиц местных жителей рисованию будАийских символов, искусству резьбы их из дерева. Аарган-Хелин первым начал обучать местное население изготовлению предметов бытовой утвари и юрточного убранства с использованием будАийских символов. ОАним из учеников Аарган-Хелина был Шыырап-Хелин, учивший в Коп-Соокском хурээ будАийскому искусству и ставший первым учителем юного Когела по изготовлению расписанных будАй̆скими символами предметов Аомашнего обихода и юрточного убранства. Аедушка Когела Мижитеевича Аелик Саая был искусным кузнецом. АеА по минии матери - кузнец и ювелир Хертек Сегбе заслужил народную славу «мастера на все руки». Отец Когела Мижитей, которого народ уважительно называц Аарган Мижитей (Кузнец Мижитей), был известным кузнецом на Хемчике и его притоках. Он был не только прекрасным кузнецом, но и великолепным мастером по Аереву, тиснению по коже, золоту и серебру. Возможно, влияние отца стало определяющим фактором развития у маленького Когела Аюбви к народному творчеству и формирования его как будущего мастера. Когел, не получивший специального художественного образования, с малых мет проявиц яркие разносторонние художественные способности, сначала вырезая фигурки животных, Аиких зверей из коры и дерева, потом - изготавливая из разных материалов мужские и женские украшения, конское снаряжение и тувинскую бытовую утварь [3].

Огромное влияние на жизненный путь Когела Саая оказали исторические события, связанные с монастырем в Коп-Сооке, возведенном в 1857 г. китайскими строителями по инициативе тувинских мам Чаалама и Аеский Аовун, по традиции того времени 
получивших образование в монгольском монастыре «Чиндан Тэнчэнмог». Первым Камбы-ламой монастыря стал очень образованный монгольский мама, прибывший по приглашению тувинских монахов. В 1912 г. в этих местах побывал VIII Богдо-гэгэн и посоветовал перенести хурээ на новое, чуть повыше, переА семью холмами, символизирующими семь чашек подношения. БогАО-гэгэн Аал название хурээ «Чоксум» и предсказал, что этот хурээ будет разрушен, но его надо будет обязательно восстановить, так как в хурээ, когда придет время, будут «кудукту кижилер» высокореализованные Учителя-перерожденцы. Еще он сказал, что со временем здесь

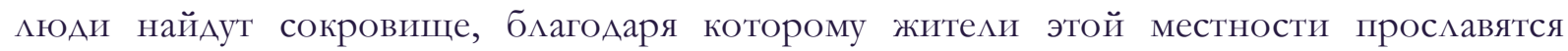
на весь мир. Им впоследствии оказался камень мягкой породы агальматолит, залежи которого находятся в неАрах Сарыг-Тайги, освященной в 1912 году VIII Богдо-гэгэном.

Монастырь перенесли на указанное место и, небольшой по размерам, он, по воспоминаниям очевидцев, имел изумительной красоты убранство, созданное под руководством ^ам-«чурагачы» (художники) послушниками хурээ и народными мастерами.

В 1935 году монастырь был сожжен. Самого сожжения четырехлетний Когел не вилел, так как в это время был в тайге, но помнит, как в течение многих дней коровы топтали сутры, разцетевшиеся далеко за территорией монастыря, а проезжавшие мимо АюАи тайком молились священным текстам, висящим на кустах. Живущие неподалеку чабаны не давали скоту затоптать место монастыря, наставляли детей не играть на этой территории и возносили подношение молоком, чтобы сожженное хурээ когАа-нибудь было восстановлено. Разрушение монастыря стало потрясением в душе маленького Когела и, сколько он себя помнит, в нем всегда жил образ того хурээ и сильное желание его восстановить.

Много мет спустя вернувшиеся из заключения мамы-«чурагачы» перешли на изготовление декоративно-прикладных изделий, бытовой утвари из дерева и природного камня-агальматолита, и постепенно искусство созАания образов будАийских божеств было забыто.

Самобытный талант Когела Мижитеевича, следовавшего траАициям своего рода, нашел выражение в декоративно-прикладном искусстве $[4,5,8,10]$. Когел Мижитеевич, переехав в село Кызыл-Ааг - родину прославленных мастеров, многому научился у знаменитого народного мастера Хертека Тойбухаа, который увидел ростки талантливого Аарования в способном ученике, осваивающем азы трудоемкой резьбы по агальматолиту. Советы и наставления Х.К. Тойбухаа сыграли большую роль в совершенствовании мастерства начинающего камнереза. Работая шофером, кузнецом-слесарем, чабаном, Когел Саая, тем не менее, внес большой вклаА в монументально-прикцадное искусство. Он созАал множество анималистических фигурок, серии скульптурных композиций, анималистические скульптуры Аля детских площадок города Кызыл, сел Кызыл-Ааг и Тээли, курорта «Уш-БелАир», принял участие в создании и оформлении декоративно-скульптурного фонтана в центре столицы республики. Его произведения стали известны в Тувинской автономной области, а с 1959 г. Когел Саая стал постоянным участником местных, зональных, всесоюзных выставок: «Советская Россия», «По родной стране», «Анималисты России», «Скульптура малых форм», «Художники автономных республик, областей, округов РСФСР», «Народное искусство СССР». Его работы выставлялись в зарубежных странах Монголии, Чехословакии, Румынии, Японии, Канаде, США. Большое художественное 
наследие мастера распространилось по многим художественным музеям России и зарубежным частным колмекциям. В 1990-е годы, период возрождения национальной культуры, ощущая потребность в развитии Аревних народных промыслов, изучая их технологии, мастер заново возродиц и обучиц своих учеников забытым видам тувинского традиционного искусства - тиснению по коже, резьбе по кости и Аереву, художественной обработке металма. Его ученики - Хулер-оол Саая, ВАадимир Салчак, Киров Хунан, Валерий Ооржак (племянник), Сергей Кочаа стали известными художниками-прикладниками, членами Союза художников СССР и России, заслуженными художниками Республики Тыва и Российской Федерации. За большой вклаА в развитие искусства Когел Мижитеевич Саая, член Союза художников России, получил звание «Заслуженный художник Тувинской АССР» (1991), высокое звание «Аауреат Государственной премии Российской Федерации» (1992), награжден Орденом Республики Тыва (2011).

Когда началось возрождение буддизма в Туве, Когел Саая, никогда не забывавший образ сожженного хурээ, сумел собрать вокруг себя мастеров-умельцев, вместе с которыми в 1990 г. возвели первый в республике будАийский монастырь в сумоне Кызыл-Ааг, недалеко от Коп-Соока (рис. 1).

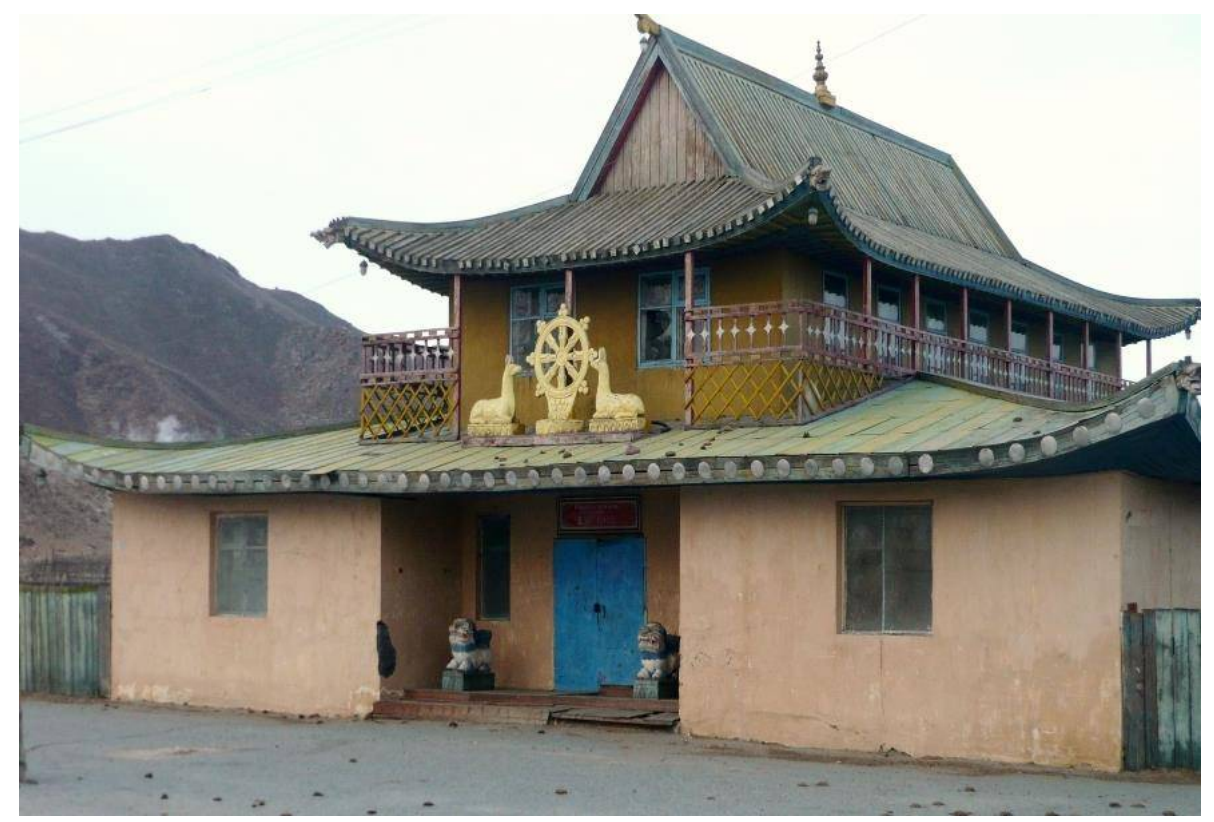

Рис. 1. Храм в с. Кыззил-Ааг Бай-Тайгинского кожууна. Источник: infourok.rи.

Местные мастера украсили территорию монастыря и его внешнее убранство. Проблемой стало украшение внутреннего убранства хурээ и ацтаря. Приобретение скульптуры в Аругих странах обходилось дорого, а готовых руководств - схем, чертежей, альбомов не было. Нашлось единственное фото с изображением божества, изготовленного по традиционной технологии Аитья из гипса и глины, которой обучал в Коп-Соокском хурээ мама-«чурагачы» Аарган-Хелин. Измерив на рисунке размеры божества Аинейкой, стали создавать пробные образы.

В поисках образов, изобразительных средств, техники и технологии изготовления будАийских божеств Когел Саая побывал в монастырях Бурятии, Монголии, Индии. В 1995 году из Индии привез три скульптуры Будды Шакьямуни. Из Монголии привез 
альбом монгольского художника Азанабадзара и, изучив его, на местном целебном источнике изготовил первую гипсовую скульптуру Белой Тары в человеческий рост. Набив руку, он изготовиц Аля алтаря Кызыл-Аагского монастыря более 100 образов будАийских божеств в мелкой пластике из гипса и глины, которые объединяет единый стиль исполнения, узнаваемый по технике и художественной выразительности. Образы отАичаются иконографическим разнообразием - это изображения БудАы Шакьямуни, Зеленой Тары, Белой Тары, Авалокитешвары в четырехрукой и одиннадцатиголовой формах, Цонкапы, Махакалы, Каларупы и Аругих божеств и защитников будАийского Учения (рис. 2, 3, 4). Тонко прорисованы детали-Аики, атрибуты, жесты, одеяния. Изображения имеют размеры 10-25 см.

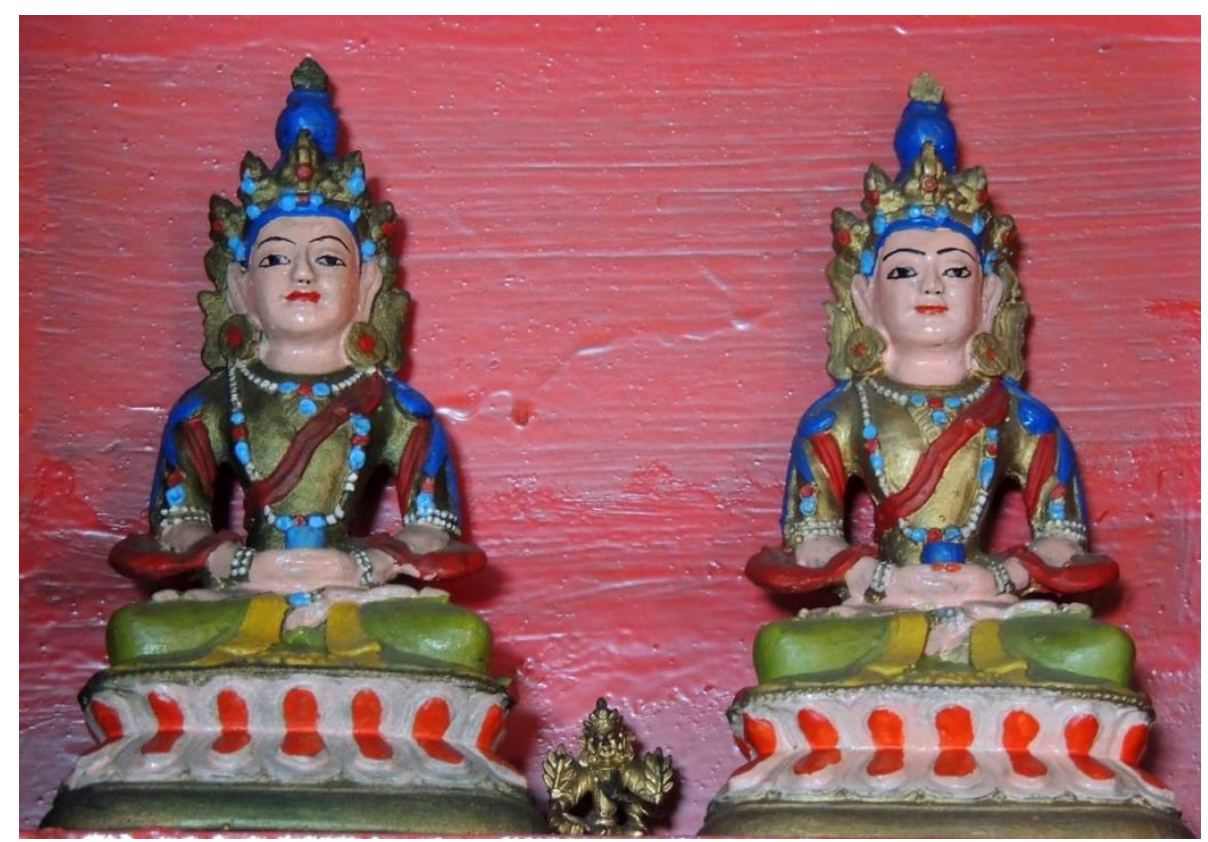

Рис. 2. Будда. Глина. Высота 15 см. Фото: А.А. Балган.

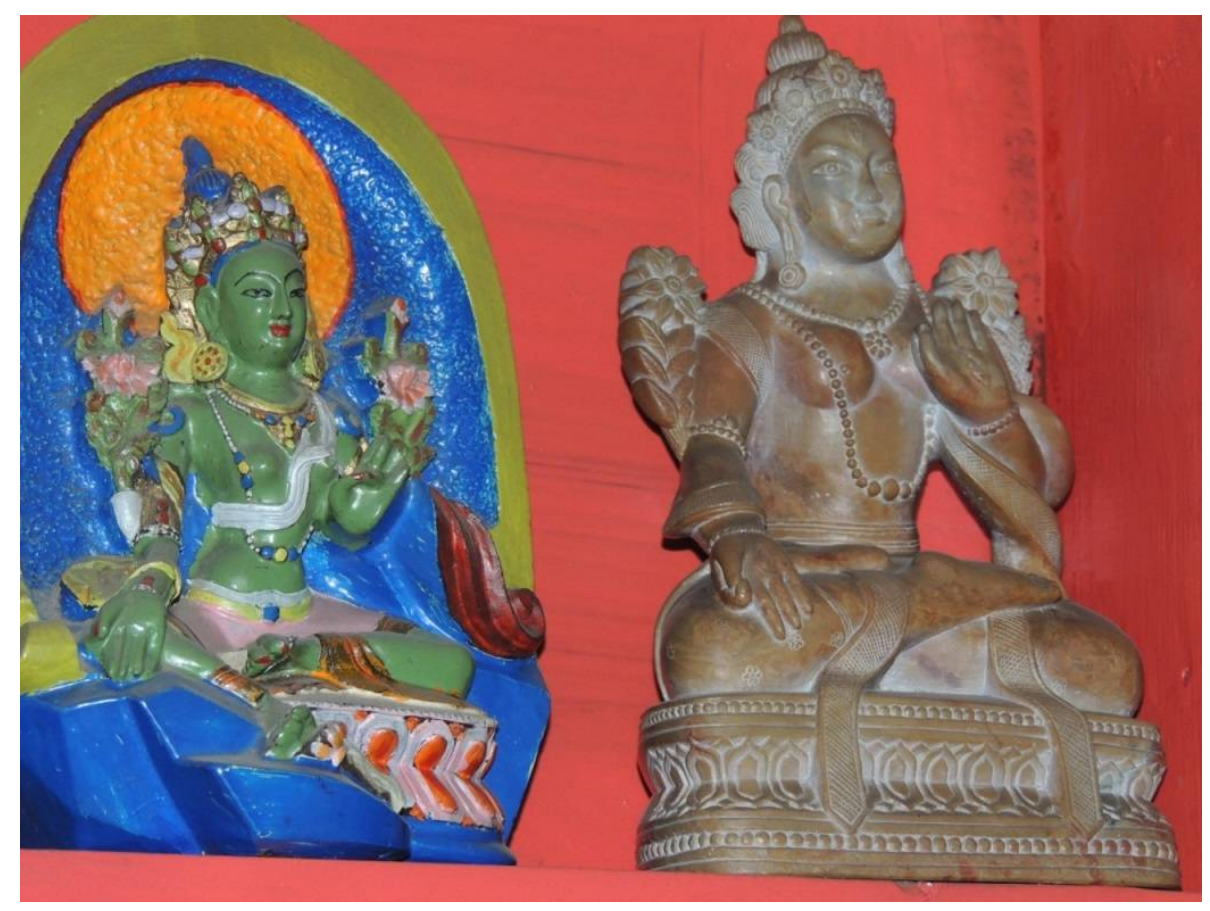

Рис. 3. Слева Зеленая Тара. Глина, высота 20 см. Справа Белая Тара. 
Агальматолит, высота 20 см. Фото: А. А. Балган.

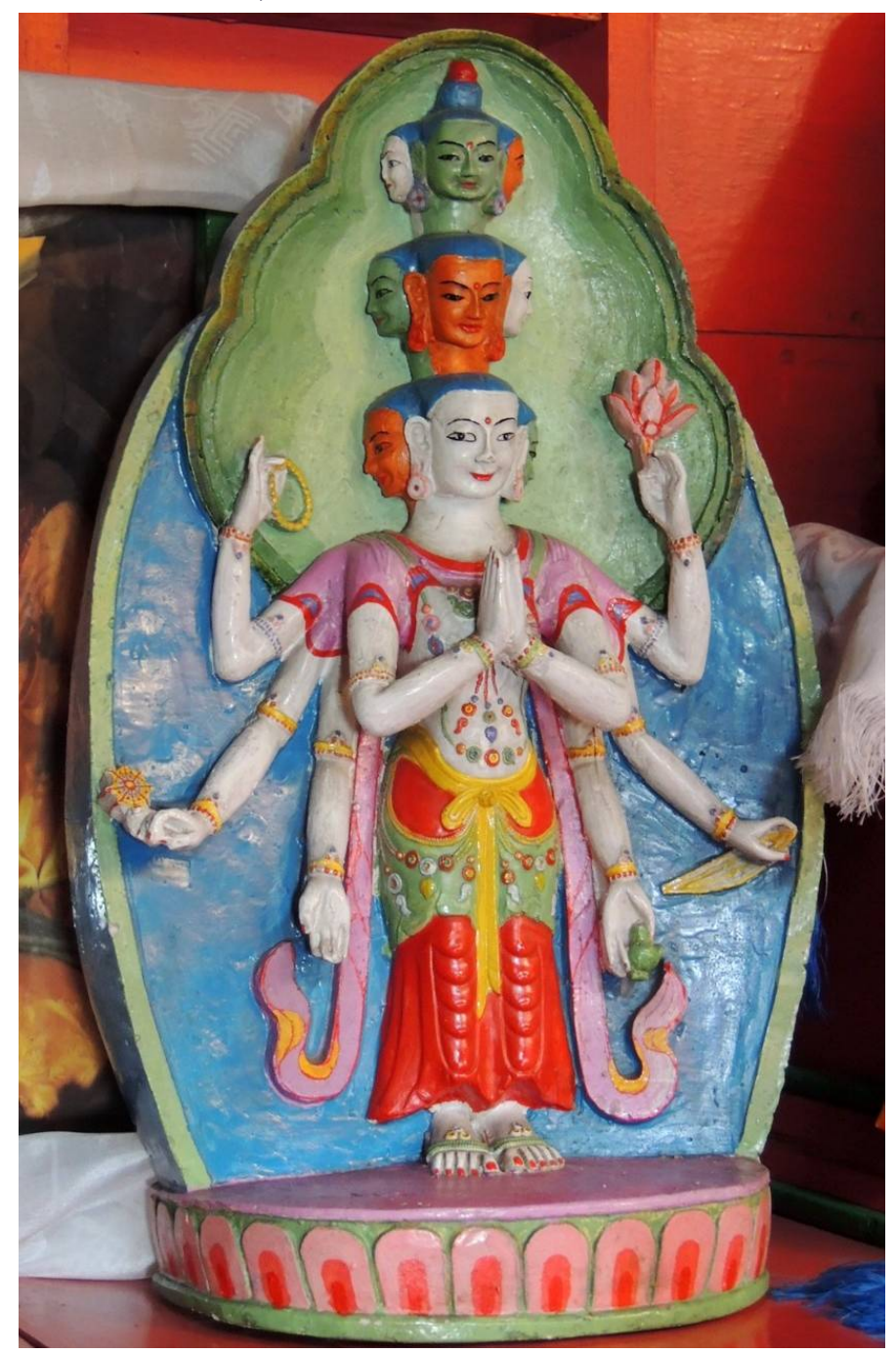

Рис. 4. Будда Авалокитешвара. Глина, высота 20 cм. Фото: А. А. Балган.

В 2010 году местные жители решили возвести молитвенный барабан на месте разрушенного Коп-Соокского монастыря. Когел Мижитеевич участвовал в подготовке сутр Аля вложения в барабан. КогАа количество текстов дошло до четырех миллионов, ему приснился сон: «На вершине горы Бай-Тайги, считающейся Матерью всех горных вершин Тувы, стоял юный Аалай-лама. Аалай-лама сказал: “Я привец Богдо-гэгэна. Он Аолжен работать зАесь, в этом монастыре” и показал рукой на монастырь, который показался неподалеку. Монастырь был окрашен в ярко-желтый цвет, а на каждой его стороне под крышей был нарисован большой глаз. Я удивился, как Аалай- ама мог подняться на такую вершину, и одновременно подмечал детали хурээ и думал, надо попробовать сАелать так. Проснулся и Аолго Аумал, что мог означать этот сон. Узнав, что в УАан-Баторе находится IX Богдо-гэгэн, я решиц туда ехать. Приехав в феврале 2011 года, попал на празднование 100-летия возведения статуи Ченрезик в монастыре Кандан. Потом помогли встретиться с Богдо-гэгэном. Узнав, что я приехал из Тувы и хочу спросить совета по поводу строительства Коп-Соокского хурээ, освященного VIII БогАО-гэгэном, он воскАикнул: "VIII БогАО-гэгэн (назвал его по имени) оставил запись о том, что в Туве он возвел монастырь Царицы-тайги, что он разрушен и его Аолжны восстановить, а сделать это АОАжен IX БогАО-гэгэн, когАа к нему придет человек и скажет, что он хочет строить этот монастырь. Я Аумац, что этот человек будет или 
тибетцем, или монголом, но никого не дожАался ни в Ахарамсале, ни в Монголии. И вот, наконец, к моей великой радости, пришел человек из Тувы. Теперь я знаю, кто будет строить этот монастырь, и могу умереть спокойно”. Богдо-гэгэн подариА мне статуэтку и сказал, что монастырь будет называться "Чоксум", а божеством-защитником его будет Очурмаанай-Ваджрапани. Я был в феврале, а 1 марта Богдо-гэгэна не стало. ВАохновленный наставлениями Учителя, я начал готовиться к работам по возрожАению хурээ».

В 2011 году по инициативе Когела Саая, которого в народе за трудолюбие называют «пчелкой», начались строительные работы по восстановлению Коп-Соокского монастыря на его историческом месте [9]. Место возведения хурээ было освящено Аосточтимым Шивалха Ринпоче. Размеры хурээ слелали чуть меньше прежних, чтобы были видны сохранившиеся обломки старого фундамента (рис. 5). Местные мастера расписывали его внутреннее и внешнее убранство, принимали участие в созАании образов божеств (рис. 6, 7). Перед монастырем местные мастера создали 16 скульптур пользующихся популярностью у верующих образов и символов - Коня ветров, несущего на спине Арагоценность «чинтамани» (символ благополучия, исполнения желаний и уникальных качеств БудАы), Арагоценного слона (символ необычных возможностей БудАы), образы мифических животных, а также животных из 12-летнего цикла восточного календаря (рис. $8,9,10)$.

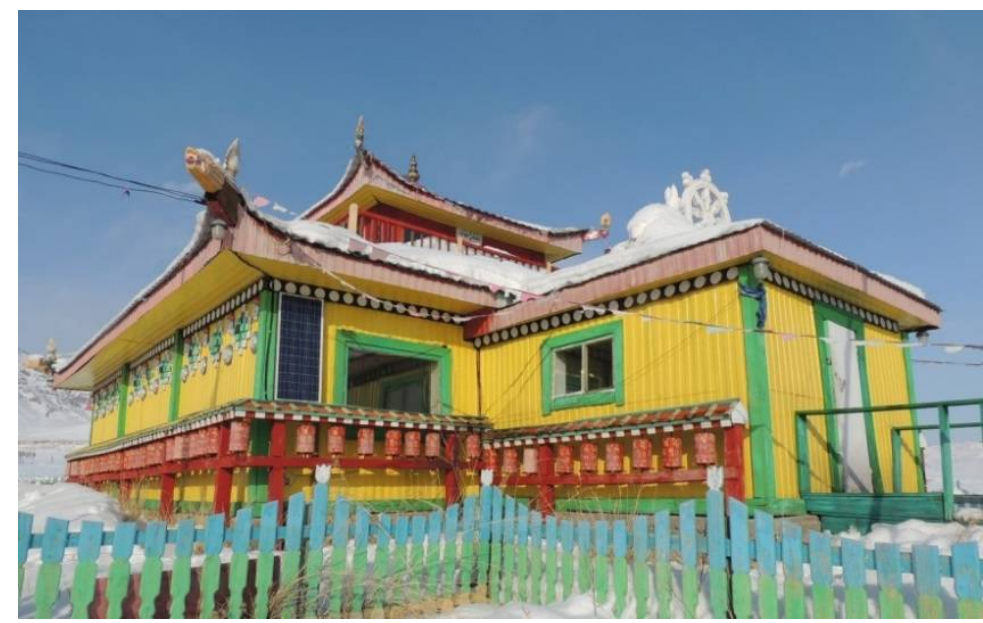

Pис. 5. Храм «Чоксум».

Фото: А.А. Балган.

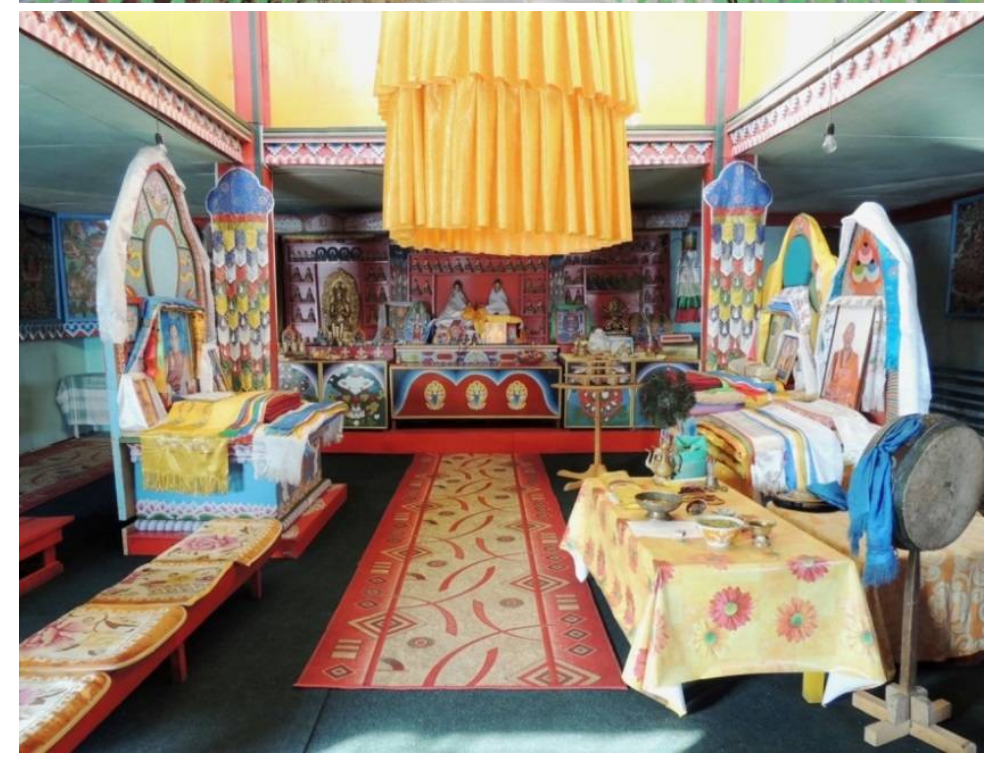

Рис. 6. Храм «Чоксум». Внутреннее убранство. Фото: А.А. Балган. 


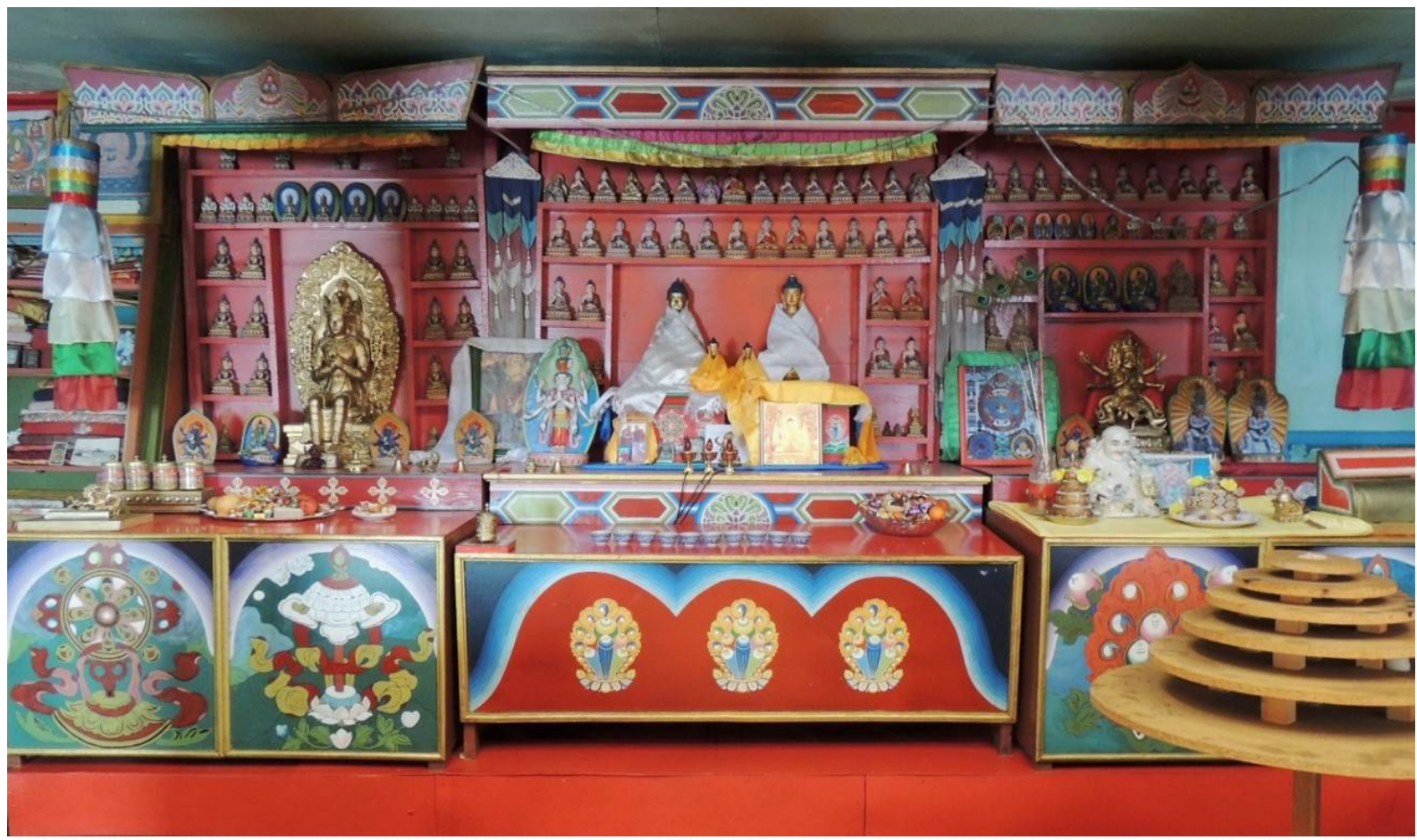

Рис. 7. Алтарь храма «Чоксум». Фото: А. А. Балган.

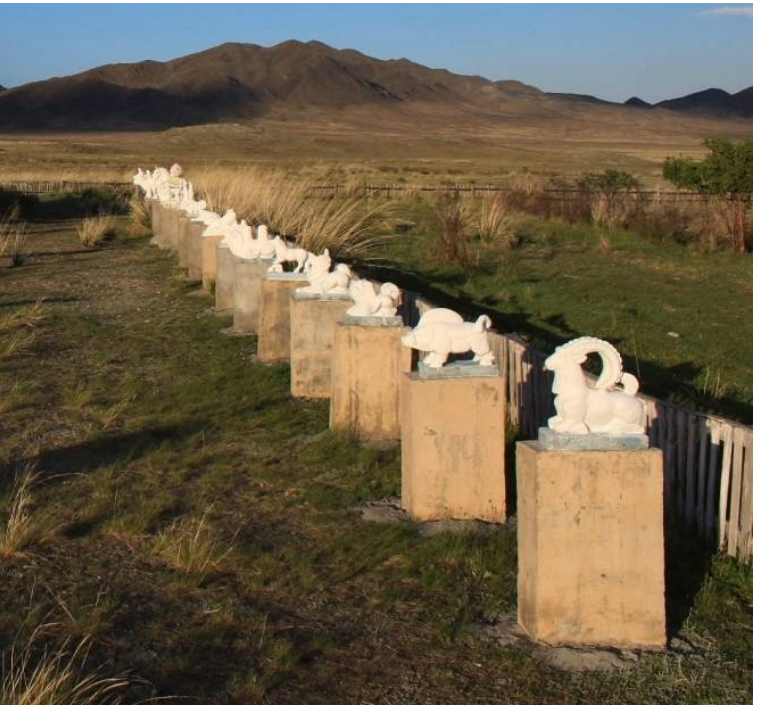

Рис. 8. Храм «Чоксум». Скульптурьи. Фото: С.А. Кужугет.

Рис. 10. Небесные львы Будды.

Фото: С.A. Кужугет.

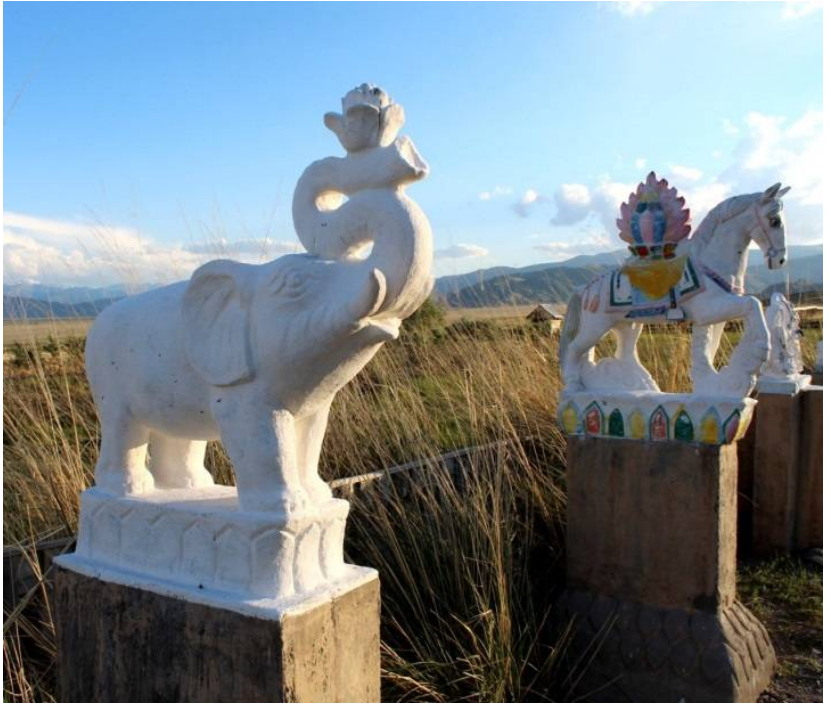

Рис. 9. Арагоченный слон и Конь ветров. Фото: С.А. Кужугет.

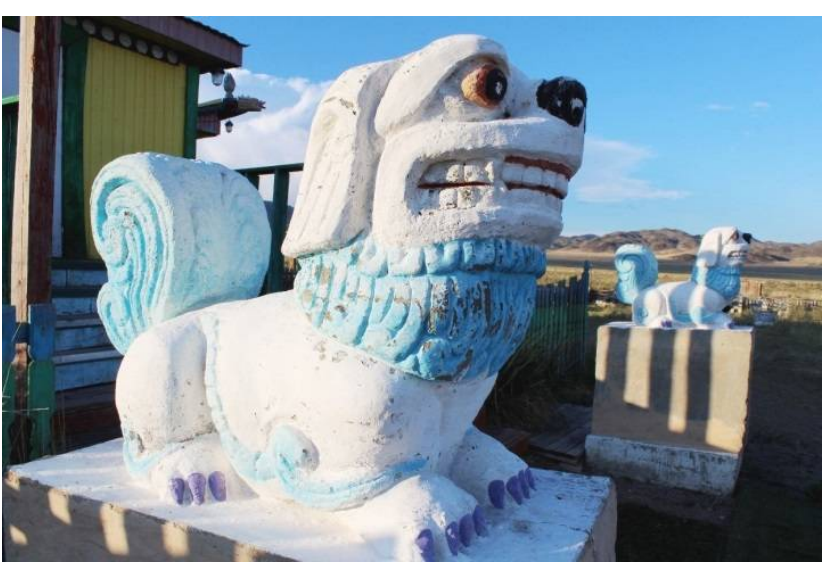


Народный мастер Тувы, камнерез Хеймер-оол Бойдосович Аонгак создал Аля алтаря статую БудАы Майтреи высотой 90 см. Статуя отлита из скульптурного гипса с тонировкой под золото с использованием меди. Аондук Хертекович Аойбухаа член Союза художников СССР и России, мауреат Государственной премии имени И.Е. Репина, преподнес в дар хурээ фигуру Белой Тары, слеланную из агальматолита.

Из хурээ Кызыл-Аага были перевезены созданные Когелом Мижитеевичем образы БудА и бодхисаттв. А^тарь также украшают изображения божеств, выполненные мастерами-камнерезами из агальматолита, и много небольших рисованных изображений будАийских божеств в гау, преподнесенных хурээ жителями.

Сутры монастырю преподнес Аоржу - сын репрессированного мамы Аамбы Салчака. После уничтожения монастыря мама Аамба Салчак сумел сохранить предметы культа и священные тексты, спасенные им при сожжении хурээ. В 1931 году он спрятал их в пещеру около скалы с петроглифами и успец показать это место своему сыну, наказав ему, чтобы тот преподнес сутры монастырю, когда он будет восстановлен. В 1990 году Аоржу Салчак выполниц предсмертную просьбу отца.

В 2014 году на церемонии открытия Коп-Соокского монастыря с участием Чадо Ринпоче и Шивалха Ринпоче Когел Мижитеевич Саая преподнес на алтарь образ БудАы Шакьямуни, подаренный ему мично Его Святейшеством Аалай-ламой. Шивалха Ринпоче сказал: «Когда ко мне за благословением пришел Когел Мижитеевич, признаться, в Ауше я сомневался, что 80-летний человек сможет построить хурээ. Я вАохновлен самоотверженностью мастера и верностью традициям тувинского народау.

В 2019 г. убранство алтаря было дополнено скульптурой Авалокитешвары, ранее созданной Когелом Мижитеевичем и отреставрированной мастером-камнерезом Тувы Аарисой Матпаковной Норбу (рис. 11).

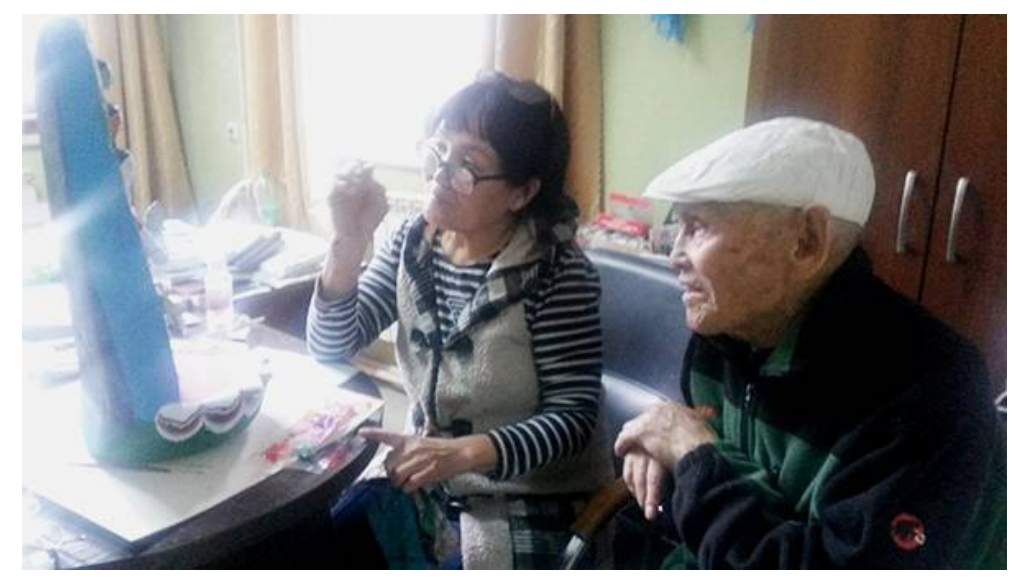

Puc. 11. K.M. Саая с мастеромкамнерезом А.М. Норбу.

Фото: А.А. Балган.

В настоящее время 88-^етний Когел Мижитеевич Саая, в 2016 г. удостоенный звания «Народный мастер Республики Тыва» (рис. 12), работает настоятелем монастыря «Чоксум», проводит молебны, ритуалы, принимает паломников, благодарит судьбу за осуществление его самой заветной мечты и каждый день возносит благопожеланияйорээл, чтобы хурээ посетили Его Святейшество XIV Аалай-лама и X Богдо-гэгеэн (рис. 13). 


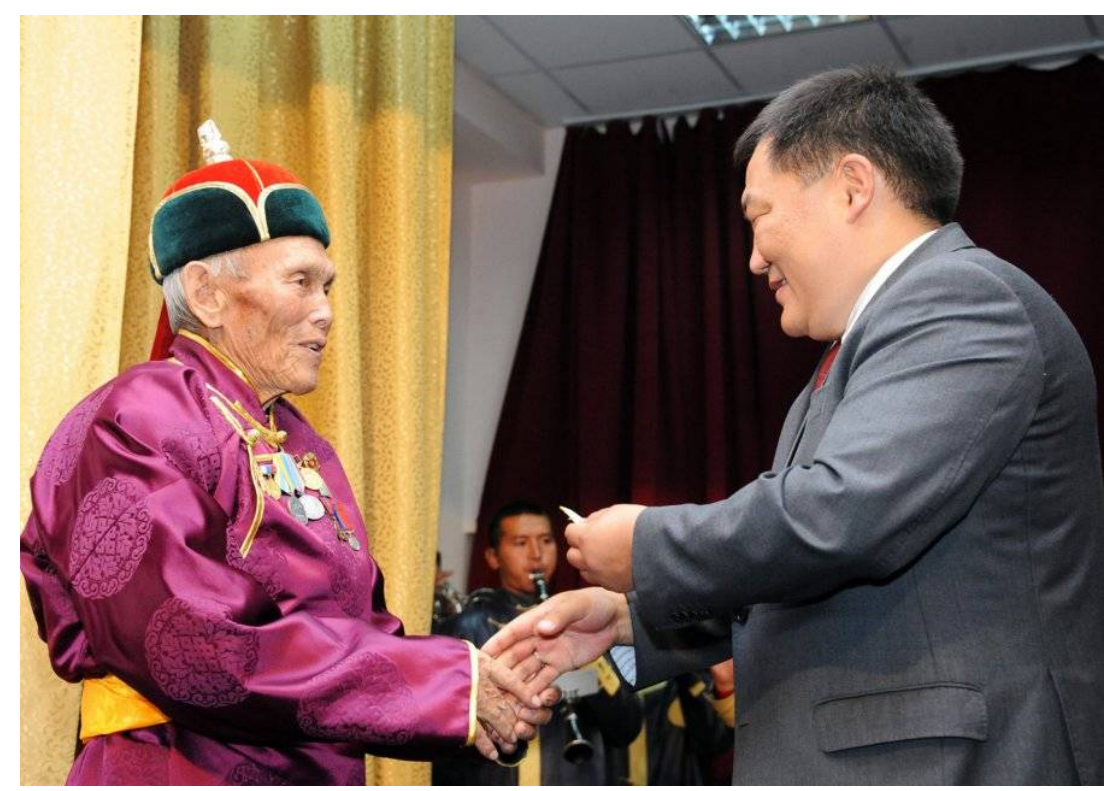

Puc. 12. K.M. Саas -

народный мастер Республики

Тыва. Вручение почетного

знака главой Республики

Тьъва Ш.В. Кара-оолом.

Источник фото:

tuvaonline.ru.

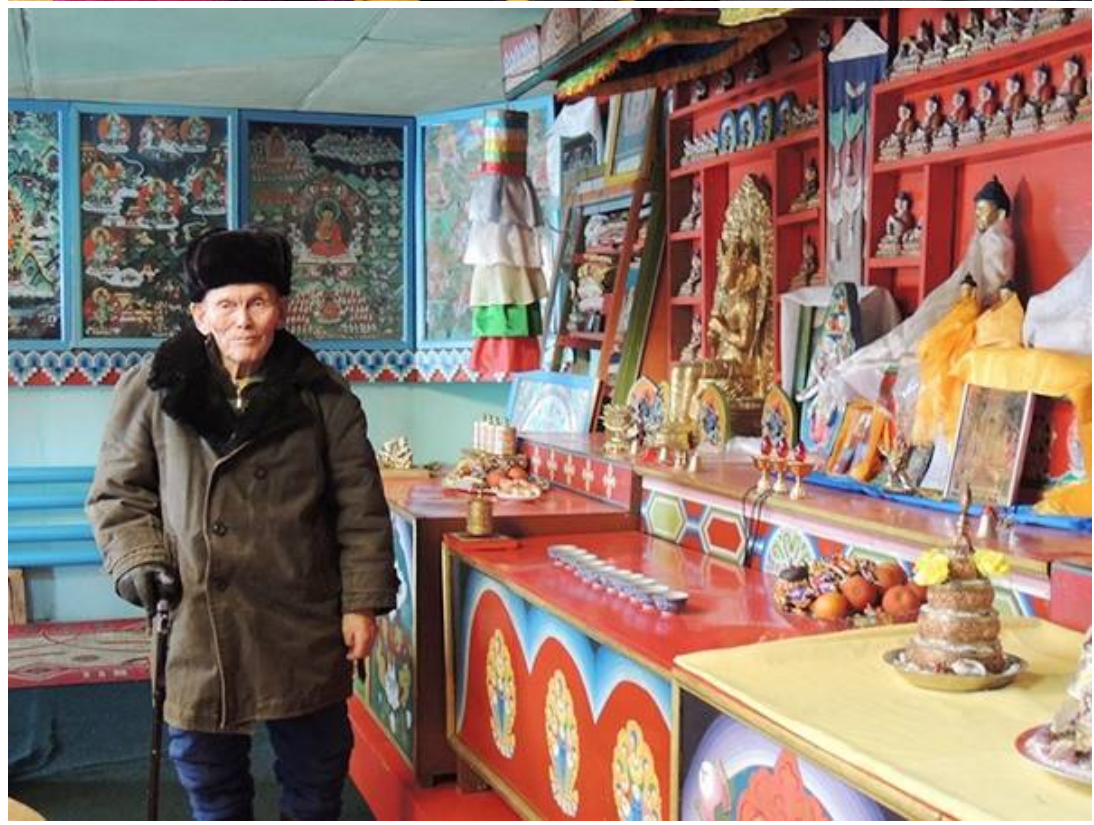

Puc. 13. K.M. Саaя

y алтаря храма «Чоксум».

Фото: А.А. Балган.

БудАийское скульптурное искусство Тувы не смогло сохраниться со всеми традициями в технике и технологии изготовления образов, тем не менее оно продолжает свое развитие. Тенденцию к дальнейшему развитию имеет начавшаяся в период возрождения буддизма традиция изготовления образов божеств из агальматолита в мелкой пластике. Камнерезные скульптурные образы будАийских божеств создаются в соответствии с будАийскими художественными традициями. В то же время творческие устремления художников направлены на поиск новых выразительных средств, имеющих эмоциональное и эстетическое воздействие. Несмотря на появившуюся возможность приобретения будАийских скульптурных образов в Индии, Монголии, Непале, Китае, изделия, созданные тувинскими мастерами, предпочитаются местным населением в качестве украшений Аомашних алтарей. Возможно, в ближайшем будущем, по мере возрастания интереса молодежи к будАийской вере, появятся новые мастера, новые художественные тенденции и технологии. 
Судьба тувинского мастера Когела Мижитеевича Саая, его скульптурные работы, украшающие Коп-Соокское хурээ, явцяются своего рода духовным заветом предков, примером Аюбви к родному краю, сбережения его культурного достояния и сохранения будАийских художественных традиций.

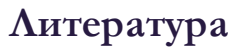

1. Будегечи Т.Б. Художественное наследие тувинцев. - М., 1995. - 151 с.

2. Монгуш М.В. История будиизма в Туве. - Новосибирск: Наука, 2001. - 200 с.

3. Салчак В.С. Сураглыг Ааш чонукчузу Саая Когел // Шын. - 2016. - №77 (18810), 12 июля. - С. 4.

4. Тулуш М. Искусство, соединяющее мюдей // Тувинская правда. - 1983. - 17 декабря. C. 4 .

5. Хертек А. Художник и пастырь / / Тувинская правда. - 2011. - 12 ноября. - С. 6.

6. Хертек А. Когел Мижитеевич Саая: к 80-летию со Аня рождения // Аетопись Тувы 2011: историко-краеведческий альманах. - Кызыл, 2010. - С. 151-153.

7. Хертек А.С. Когел Саая. Резьба по камню. Творческая биография. Буклет НИРТ. Кызыл, 2006.

8. Хертек Т. Шуураан теннин самы: даш чонукчузу К.М. Саая 75 харлаан // Известия Тувы. - 2006. - 13 июля. - С. 3.

9. Оюн А. Саая Когел восстанавливает старинный будцийский храм в Бай-Тайге [ЭАектронный ресурc]. URL: https://www.tuvaonline.ru/2012/07/17/saaya-kogel-vosstanavlivaetstarinnyy-buddiyskiy-hram-v-bay-tayge.html (Аата обращения 08.07.2019).

10. Иргит А.К. Саая Когел Мижитеевич - учитель, продолжатель традиций народного искусства Тувы // Вестник Тувинского государственного университета. Педагогические науки. - 2018. - № 4. - С. 13-16.

11. Аажы-Аамб̆а Н. Увлеченный // Тувинская правда. - 1968. - 1 мая. - С. 4.

Статья поступила в редакцию 29.07.2019 г. 


\title{
TRADITIONS OF TUVAN BUDDHIST ART IN THE WORK OF THE MASTER KOGEL SAAYA
}

Balgan Ailana Arysh-oolovna

Specialist of the department of folk arts and crafts and decorative arts at the Center of Development of Tuvan Traditional Culture and Crafts.

Russia, Kyzyl.

a.balgan@mail.ru

\begin{abstract}
An important place in the spiritual culture of the Tuvan people is occupied by Buddhist art, which has experienced periods of prosperity, oblivion, and rebirth for a century. The article discusses the work of the Tuvan master Kogel Mizhiteevich Saaya, who made a great contribution to the revival of Buddhist art in Tuva.

Keywords: Buddhist art, arts and crafts, Buddhist monastery, folk craftsmen, Kogel Saaya, tradition.

Bibliographic description for citation:

Balgan A.A. Traditions of Tuvan Buddhist art in the work of the master Kogel Saaya. Iskusstvo Evrazii - The Art of Eurasia, 2019, No. 3 (14), pp. 74-86. DOI: 10.25712/ASTU.25187767.2019.03.005. Available at: https://readymag.com/u50070366/1483113/13/(In Russian).
\end{abstract}

\section{References}

1. Budegechi T. B. Khudozhestvennoe nasledie tuvintsev [Artistic heritage of Tuvans]. Moscow, 1995. $151 \mathrm{p}$.

2. Mongush M.V. Istoriya buddizma $v$ Tuve [The history of Buddhism in Tuva]. Novosibirsk, Nauka, 2001. 200 p.

3. Salchak V.S. Suraglyg dash chonukchuгu Saaya Kogel. Shyn - Shyn, 2016, No. 77(18810), July 12, P. 4. (In Tuvan).

4. Tulush M. Iskusstvo, soedinyayushchee lyudei [The art connecting people]. Tuvinskaya pravaTuva truth, 1983, December 17, p. 4.

5. Khertek A. Khudozhnik i pastyr' [The artist and the shepherd]. Tuvinskaya prava - Tuva truth, 2011, November 12, p. 6.

6. Khertek A. Kogel Mizhiteevich Saaya: k 80-letiyu so dnya roz̧deniya [Kogel Mizhiteevich Saaya: on the occasion of the 80th birthday]. In: Letopis' Twy - 2011 [Chronicle of Tuva 2011]. Kyzyl, 2010, pp. 151-153.

7. Khertek A.S. Kogel Saaya. Rez'ba po kamnyu. Tvorcheskaya biografiya [Kogel Saaya. Stone carving. Creative biography]. Kyzyl, 2006.

8. Hertek T. Shuuraan Tennina Samy: Dash Chonukchuzu K.M. Saaya 75 Harlaan. In: Izvestiya Tuvy - News of Tuva, 2006, July 13, p. 3. (In Tuvan). 
9. Oyun D. Saaya Kogel vosstanavlivaet starinnyi buddiiskii khram v Bai-Taige [Saaya Kogel restores an ancient Buddhist temple in Bai Taiga]. Available at: https:/ / www.tuvaonline.ru/2012/07/17/ saaya-kogel-vosstanavlivaet-starinnyy-buddiyskiyhram-v-bay-tayge.html (accessed 08.07.2019).

10. Irgit A.K. Saaya Kogel Miæhiteevich - uchitel', prodolzhatel' traditsii narodnogo iskusstva Tuvy [Saaya Kogel Mizhiteevich - teacher, successor of the traditions of folk art of Tuva]. Vestnik Tuvinskogo gosudarstvennogo universiteta. Pedagogicheskie nauki - Bulletin of Tuva State University. Pedagogical sciences, 2018, No. 4, p. 13-16.

11. Dazhy-Damba N. Uvlechennyi [Enthusiastic]. Tuvinskaya prava - Tuva truth, 1968, May 1, p. 4.

Received: July 29, 2019. 